\title{
A Study on the Knowledge and Attitudes According to the Presence of Drinking Education for High School Students
}

\author{
Jin- Sook Han $^{1}$, Yong-Ha Kim ${ }^{2}$ and Kwang-hwan Kim ${ }^{2 *}$ \\ ${ }^{1}$ Department of Nursing, Konyang University, Gasoowon-dong, Seo-gu, \\ Daejeon, Korea \\ ${ }^{2}$ Department of Hospital management, Konyang University, Gasoowon-dong, Seo-gu, \\ Daejeon, Korea \\ jshan@konyang.ac.kr,kyh@konyang.ac.kr,kkh@konyang.ac.kr
}

\begin{abstract}
This study was executed to identify the presence of drinking education and associated drinking knowledge and attitudes of high school students in some areas. Sample data were collected from 211 high school students in D city from March $4^{\text {th }}$ to March $8^{\text {th }}$ in 2013. Structured self-administered questionnaires were used as survey tool. Study results showed drinking knowledge of some high school students was the highest score in that 'daily life is difficult when addicted to alcohol', and showed the lowest score in that 'alcohol does not affect the brain.' ( $p<0.05)$. According to the presence of education, results showed high score when the students received the drinking education that 'alcohol is prohibited to minors' ( $p<0.05)$. Regarding drinking education place, school showed the highest percentage of 92.4\%, which is much higher than that of other institutions. Regarding education methods, lecture and video watching had the highest percentage of $47.5 \%$ and regarding educators, external lecturers had the highest percentage of 53.3. In order to examine the knowledge and attitudes according to the presence of drinking education, Logistic Regression Analysis was conducted and the results showed that the knowledge was estimated to improve 0.9 times and attitudes were estimated to improve 1.22 times. These results are considered to be utilized as fundamental data for re-emphasizing the necessity of youth drinking education and for drinking education program for those young people.
\end{abstract}

Keywords: High school students, drinking education, drinking knowledge, drinking attitude

\section{Introduction}

As the ages of Korean youths are decreasing, recent interest about youth drinking is increasing. Average age of their first drinking experience dropped to 13.2 years old in early 2000 and drinking rate of middle school students has recorded two digits. Even though the rate recently dropped a little, average drinking rate of male and female general high school students has reached $24 \%$. This phenomenon is somewhat faster, compared with that of other countries [1].

Youth drinking is an important forecasting factor of alcohol dependence and addiction in adulthood [2]. In addition, it gives influences not only on cardiovascular system but also on mental nerve systems, which increases depressions resulting from alcohol, and depressions

\footnotetext{
*Corresponding author: Kwang-hwan Kim(Konyang University) kkh@konyang.ac.kr
} 
may affect their self-esteem. Young people who have low self-esteem are likely to provoke violence or suicide [3]. Furthermore, it increases sexual experiences and sexual assaults. In addition, alcohol brings crime, violence and mental problems as well [4, 5].

In addition, alcohol degrades memory loss and the ability to learn, causing loss of interest in learning. Drinking alcohol in adolescents makes it difficult to change the perception on drinking when grown to adults, so it affects to cause illness. These impacts will cause the loss of the balance in health, influencing the life of a human being. Therefore, youth drinking is not the problem to overlook and pass lightly from the perspective of the public health concerning the health of the nation. It is about time positive efforts and concrete actions were required to lower the drinking rate of youth.

From old times, youth drinking was not seriously considered because of general drinking cultures of older generation; but in recent years, this problem emerged as social problems as drinking problems and misconducts of young people increased. There are not many schools or community level drinking prevention programs that can control the increasing youth drinking culture. While the need for alcohol prevention is recognized, systematic and practical operation of alcohol prevention programs is lacking. That is why the national level, but minimal control of alcohol is being reinforced. Therefore, Department of Health and Human Services came to show the intention to make healthy Korea by adopting the drinking moderation policy of developed countries. Thanks to these efforts, 37 percent of average drinking rate of general high school male and female students in 2005 has been gradually decreasing and subsequently decreased to $24.2 \%$ in 2012 [6]. Contents of drinking moderation policy are mainly to appoint drinking advertising and sales and drinking forbidden places.

However, regarding the drinking of young people who are in the growth period, drinking education in family and school is desperately required as well as the minimum legal regulations. In addition, to make older generation recognize the importance of drinking problems of young people is very important as well [7]. And therefore, it is desirable that the best drinking education should take place at home. However, because drinking education is not practically done well at home, changes in understanding about alcohol through systematic drinking education at school is very important. Adolescence is the period when the change in awareness and behavior is expected to be possible through education. In other words, active drinking education for young people is required in order that various harmful effects could be prevented through drinking education for young people and consequent changes of their drinking recognition and attitudes. Komro [8] asserted that the drinking number of young people who had drinking education with applied drinking education program has decreased, which showed this drinking education was effective to young people.

Therefore, this study was executed to provide the basic data for drinking prevention programs when seek drinking culture improvement plans for young people that continue to increase every year, by identifying high school students' drinking education realities and drinking related knowledge and attitudes.

\section{Methods}

\subsection{Data collection}

Subjects were collected with 211 second grade high school students in D city for 1 week from 2013 March $4^{\text {th }}$ to March $8^{\text {th }}$. Data collection was conducted by trained interviewers in advance after the interviewers get the approval of the principal and explained the purpose and writing standards of the survey and let the study subjects fill out the paper with selfadministered method. 


\subsection{Instrument}

As examining tools, validity verified survey papers were used which were suitable for high school students. For drinking survey, international standards materials about the degree of alcohol use and survey papers of Korean Public Health Association were used to identify the drinking facts. Survey papers were composed of total of 26 questions including 3 questions about general characteristics, 10 questions about drinking knowledge, 10 questions on drinking attitudes and 3 questions about drinking education.

Each question is measured with 5-point Likert scales. (Very satisfactory 5 point, satisfactory 4 point, normal 3 point, unsatisfactory 2 point, very unsatisfactory 1 point).

\subsection{Data analysis}

Collected data were input in computer and analyzed through SPSSWIN (ver. 11.0) program. Cross-analysis was conducted to identify the relationships of the variables according to the presence of drinking education of study subjects and t-test was conducted to compare the differences of drinking knowledge and attitudes according to each independent variables. In addition, in order to identify the influences of each independent variable about the presence of drinking knowledge, multiple regression analysis was performed by scoring drinker as 0 and non-drinker with 1.

\section{Results}

\subsection{General characteristics of subjects}

General characteristics of total of 211 subjects showed 119 not-educated (43.6\%) subjects and 92 educated (54.6\%) subjects; not educated subjects had higher distribution than educated subjects. Presence of education according to age showed higher distribution in 17 years old students than 18 years old students. Regarding religions, no-religion showed the highest percentage of $64.9 \%$ and catholic showed the lowest percentage of $4.7 \%$ and similar tendencies according to the presence of drinking education. Regarding living standards, class 'Fair' showed the highest percentage of $62.6 \%$ and class "good" showed the lowest percentage and showed similar distributions according to the presence of education (Table 1).

Table 1. General characteristic unit of subject: $\mathbf{N}(\%)$

\begin{tabular}{|l|l|l|l|}
\hline General characteristics & Educated & Not-educated & Total \\
\hline Ages & & & \\
\hline 17 & $66(71.7)$ & $82(68.9)$ & $148(70.1)$ \\
\hline 18 & $26(28.3)$ & $37(31.1)$ & $63(29.9)$ \\
\hline Religion & & & \\
\hline Christian & $15(16.3)$ & $18(15.1)$ & $33(15.6)$ \\
\hline Buddhist & $14(15.2)$ & $17(14.3)$ & $31(14.7)$ \\
\hline Catholic & $6(6.5)$ & $4(3.4)$ & $10(4.7)$ \\
\hline No-religion & $57(62.0)$ & $80(67.2)$ & $137(64.9)$ \\
\hline Living standard & & & \\
\hline Good & $13(14.1)$ & $13(10.9)$ & $26(12.3)$ \\
\hline Fair & $56(60.9)$ & $76(63.9)$ & $132(62.6)$ \\
\hline Poor & $23(25.0)$ & $30(25.2)$ & $53(25.1)$ \\
\hline Total & $92(43.6)(100.0)$ & $119(54.6)(100.0)$ & $211(100.0)(100.0)$ \\
\hline
\end{tabular}




\subsection{Knowledge and attitudes according to the presence of drinking education}

Knowledge category according to the presence of drinking education showed the highest point of 4.58 in that "Alcohol addiction makes daily life difficult" and showed 4.1 point in that "cause psychosis when alcohol addicts stop drinking" and showed the lowest point of 1.70 in that "Alcohol does not affect the brain." Depending on the presence of Education, the case when alcohol is prohibited showed 4.51 point, which is higher point than the case with 4.44 point when alcohol is not prohibited. $(\mathrm{p}<0.05)$ and the other cases showed similar tendencies. At drinking attitudes category, highest point was 3.80 in that "Youth drinking is not good", and 3.59 point in that "Drinking is positive because a few glasses of drinking are not harmful", 3.55 point in that "Adults have to rink for sociability" and 1.78 point in that "Drinking impulse comes out when watching drinking ads". According to the presence of Education, all categories showed similar tendencies (Table 2).

Table 2. Knowledge state

unit: (Mean \pm S.D.)

\begin{tabular}{|c|c|c|c|c|c|}
\hline Characteristics & Educated & $\begin{array}{l}\text { Not } \\
\text { educated }\end{array}$ & Total & $\mathrm{t}$ & $\begin{array}{l}\mathrm{p}- \\
\text { value }\end{array}$ \\
\hline \multicolumn{6}{|l|}{ Knowledge state about drinking } \\
\hline Alcohol produces calories. & $3.74 \pm 1.00$ & $3.65 \pm 1.10$ & $3.69 \pm 1.06$ & 0.623 & 0.534 \\
\hline Alcohol does not affect the brain. & $1.62 \pm 1.10$ & $1.76 \pm 1.11$ & $1.70 \pm 1.06$ & -0.977 & 0.329 \\
\hline Alcohol is prohibited to minors. & $4.51 \pm 0.89$ & $4.39 \pm 1.13$ & $4.44 \pm 1.03$ & 3.605 & 0.050 \\
\hline $\begin{array}{l}\text { Heavy drinking causes gastritis or peptic } \\
\text { ulcer. }\end{array}$ & $4.46 \pm 0.68$ & $4.43 \pm 0.74$ & $4.44 \pm 0.71$ & 0.280 & 0.780 \\
\hline $\begin{array}{l}\begin{array}{l}\text { Alcohol addiction makes } \\
\text { difficult. }\end{array} \\
\end{array}$ & $4.60 \pm 0.72$ & $4.57 \pm 067$ & $4.58 \pm 0.69$ & 0.273 & 0.785 \\
\hline $\begin{array}{l}\text { Cause psychosis when alcohol addicts stop } \\
\text { drinking. }\end{array}$ & $4.54 \pm 0.68$ & $4.48 \pm 0.73$ & $4.51 \pm 0.71$ & 0.651 & 0.516 \\
\hline $\begin{array}{l}\text { About } 80 \% \text { of alcohol is absorbed in the } \\
\text { stomach. }\end{array}$ & $3.08 \pm 1.29$ & $3.25 \pm 1.31$ & $3.18 \pm 1.30$ & -0.970 & 0.333 \\
\hline $\begin{array}{l}\text { If suitable, it becomes a medicine, but if } \\
\text { excessive, it becomes a poison. }\end{array}$ & $4.43 \pm 0.82$ & $4.33 \pm 0.93$ & $4.37 \pm 0.88$ & 0.868 & 0.386 \\
\hline Alcohol directly damages to liver cells. & $4.18 \pm 0.91$ & $4.24 \pm 0.88$ & $4.22 \pm 0.89$ & -0.474 & 0.636 \\
\hline $\begin{array}{l}\text { Death risk when Blood alcohol } \\
\text { concentration(BAC) is more } 0.5 \% \text {. }\end{array}$ & $3.55 \pm 1.00$ & $3.50 \pm 1.08$ & $3.53 \pm 1.05$ & 0.342 & 0.732 \\
\hline \multicolumn{6}{|l|}{ Attitudes toward drinking } \\
\hline $\begin{array}{l}\text { No problem to sequel and think drinking } \\
\text { when feel comfortable. }\end{array}$ & $3.18 \pm 1.20$ & $3.03 \pm 1.36$ & $3.09 \pm 1.29$ & 0.887 & 0.376 \\
\hline Think of drinking when stressed. & $2.52 \pm 1.28$ & $2.61 \pm 1.43$ & $2.57 \pm 1.36$ & -0.437 & 0.662 \\
\hline Youth drinking is not good. & $3.70 \pm 1.21$ & $3.87 \pm 1.07$ & $3.80 \pm 1.13$ & -1.129 & 0.260 \\
\hline $\begin{array}{l}\text { Drinking is positive because a few glasses } \\
\text { of drinking are not harmful. }\end{array}$ & $3.70 \pm 1.05$ & $3.51 \pm 1.13$ & $3.59 \pm 1.10$ & 1.198 & 0.232 \\
\hline Feel like to be an adult when drinking. & $1.86 \pm 1.03$ & $2.07 \pm 1.25$ & $1.98 \pm 1.16$ & -1.292 & 0.198 \\
\hline $\begin{array}{l}\text { Drinking impulse comes out when } \\
\text { watching drinking ads. }\end{array}$ & $1.74 \pm 0.98$ & $1.81 \pm 1.13$ & $1.78 \pm 1.07$ & -0.452 & 0.650 \\
\hline Adults have to rink for sociability. & $3.74 \pm 1.06$ & $3.40 \pm 1.28$ & $3.55 \pm 1.24$ & 2.072 & 0.039 \\
\hline $\begin{array}{l}\text { Can't allow the drinking of opposite sex } \\
\text { friend. }\end{array}$ & $2.10 \pm 0.96$ & $2.29 \pm 1.24$ & $2.21 \pm 1.13$ & -1.251 & 0.212 \\
\hline $\begin{array}{l}\text { Need to strengthen the enforcement of } \\
\text { drinking at school }\end{array}$ & $2.71 \pm 1.13$ & $2.74 \pm 1.19$ & $2.73 \pm 1.16$ & -0.230 & 0.839 \\
\hline $\begin{array}{l}\text { Will stop drinking even after becoming an } \\
\text { adult. }\end{array}$ & $2.09 \pm 1.20$ & $2.48 \pm 1.33$ & $2.31 \pm 1.28$ & -2.240 & 0.026 \\
\hline
\end{tabular}




\subsection{Drinking education}

Drinking education places showed $92.4 \%$ at school which is significant higher percentage than at other institutions. Education methods showed the highest percentage of $45.7 \%$ through lectures and video watching, $25 \%$ through lectures, $22.8 \%$ through video watching and the lowest $6.5 \%$ through other methods.

Regarding educators, external lecturers showed the highest percentage of $53.3 \%$, department teachers showed $31.5 \%$, health teacher showed $9.8 \%$ and others showed the lowest percentage of $5.4 \%$ (Table 3 ).

Table 3. Drinking education

\begin{tabular}{|l|l|l|}
\hline General characteristics & Educated & $\%$ \\
\hline Educating places & \multicolumn{2}{l|}{} \\
\hline School & 85 & 92.4 \\
\hline Family & 6 & 6.5 \\
\hline Counseling institution & 1 & 1.1 \\
\hline Education methods & \multicolumn{2}{l|}{} \\
\hline Lecture & 23 & 25.0 \\
\hline Video watching & 21 & 22.8 \\
\hline Lecture + video watching & 42 & 45.7 \\
\hline Others & 6 & 6.5 \\
\hline Educator & \multicolumn{2}{|l|}{} \\
\hline Department teacher & 29 & 31.5 \\
\hline Health teacher & 9 & 9.8 \\
\hline External lecturer & 49 & 53.3 \\
\hline Others & 5 & 5.4 \\
\hline Total & 92 & 100.0 \\
\hline
\end{tabular}

\subsection{Logistic Regression according to the status of the educational knowledge and attitudes}

In order to identify the knowledge and attitudes according to the presence of drinking education, Logistic Regression Analysis was conducted and the results showed that knowledge was predicted to be improved by 0.9 times and attitudes were predicted to be improved by 1.22 times (Table 4 ).

Table 4. Logistic Regression according to the status of the educational knowledge and attitudes

\begin{tabular}{|l|l|l|l|l|l|l|}
\hline \multirow{2}{*}{ Variables } & \multirow{2}{*}{$\mathrm{B}$} & \multirow{2}{*}{$\mathrm{SE}$} & \multirow{2}{*}{ Wald } & \multirow{2}{*}{ EXP(B) } & \multicolumn{2}{|l|}{ 95\% CI for Exp(B) } \\
\cline { 6 - 8 } & & & & & Lower & Upper \\
\hline Age & 0.109 & 0.311 & 0.124 & 1.116 & 0.607 & 2.051 \\
\hline Living standard & 0.094 & 0.238 & 0.155 & 1.098 & 0.689 & 1.752 \\
\hline Knowledge & -0.071 & 0.320 & 0.049 & 0.932 & 0.498 & 1.744 \\
\hline Attitudes & 0.205 & 0.281 & 0.532 & 1.227 & 0.708 & 2.129 \\
\hline Constant & -2.219 & 5.449 & 0.166 & 0.109 & & \\
\hline
\end{tabular}




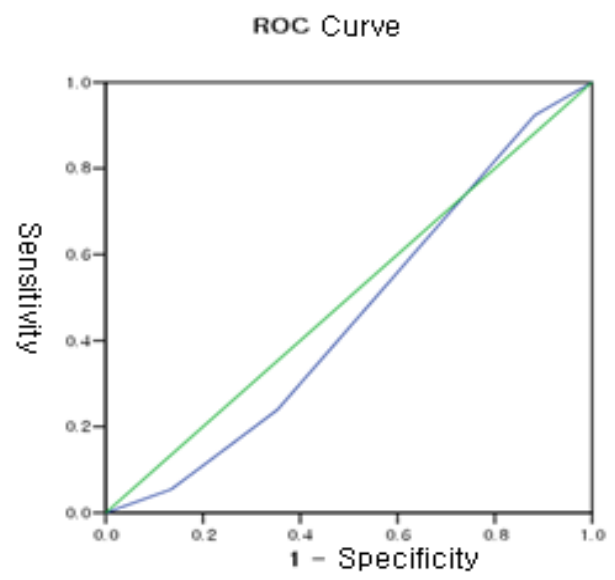

\subsection{Relevance according to drinking status}

Relevance according to drinking status showed significant relevance in living standard according to ages $(\mathrm{r}=0.198, \mathrm{p}<0.001)$, necessity of sobriety education $(\mathrm{r}=$ $0.174, \mathrm{p}<0.05)$ and fulfillment status after sobriety education $(\mathrm{r}=0.030, \mathrm{p}<0.00)$. School grades showed relevance in sobriety education necessity $(r=-0.151, p<0.05)$ and sobriety attitudes $(\mathrm{r}=0.160, \mathrm{p}<0.05)$ and reading sobriety education necessity, results showed statistically significant differences in fulfillment status after sobriety education $(\mathrm{r}=0.497, \mathrm{p}<0.05)$ and attitudes about sobriety $(0.142, \mathrm{p}<0.05)($ Table 5$)$.

Table 5. Relevance according to drinking status

\begin{tabular}{|c|c|c|c|c|c|c|}
\hline & Age & $\begin{array}{l}\text { Living } \\
\text { standard }\end{array}$ & $\begin{array}{l}\text { School } \\
\text { grades }\end{array}$ & $\begin{array}{l}\text { Necessity of } \\
\text { sobriety } \\
\text { education }\end{array}$ & $\begin{array}{l}\text { Fulfillment } \\
\text { after sobriety } \\
\text { education }\end{array}$ & $\begin{array}{l}\text { Knowledge } \\
\text { about } \\
\text { sobriety }\end{array}$ \\
\hline $\begin{array}{l}\text { Living } \\
\text { standard }\end{array}$ & $0.189 * *$ & & & & & \\
\hline $\begin{array}{l}\text { School } \\
\text { grades }\end{array}$ & 0.095 & -0.096 & & & & \\
\hline $\begin{array}{l}\text { Necessity } \\
\text { of sobriety } \\
\text { education }\end{array}$ & $0.174 *$ & 0.059 & $-0.151 *$ & & & \\
\hline $\begin{array}{l}\text { Fulfillment } \\
\text { after } \\
\text { sobriety } \\
\text { education }\end{array}$ & $0.303 * *$ & -0.124 & -0.047 & 0.497 * & & \\
\hline $\begin{array}{l}\text { Knowledge } \\
\text { about } \\
\text { sobriety }\end{array}$ & 0.004 & -0.052 & 0.052 & -0.090 & 0.082 & \\
\hline $\begin{array}{l}\text { Attitudes } \\
\text { toward } \\
\text { sobriety }\end{array}$ & 0.017 & -0.096 & $0.160 *$ & $-0.142 *$ & -0.072 & 0.007 \\
\hline
\end{tabular}

\section{Conclusions}

At the category of drinking knowledge according to the presence of drinking education, all subjects responded 'day-to-day life is difficult when addicted to alcohol' and drinking educated students showed higher distribution in 'alcohol should be 
prohibited to minors' $(\mathrm{p}<0.05)$. This could be interpreted high school students recognize negative effects of alcohol and the necessity of drinking education. In other words, it is necessary that drinking cultures should be improved by prohibiting drinking behaviors in school like drinking moderation policy which was jointly conducted by Ministry of Health and Welfare and Korea Centers for Disease Control and Prevention, or by minimizing the opportunities that minors can meet the alcohol. This shows the necessity to educate high school students in order that they should voluntarily prohibit minors from drinking alcohol by learning the influences of alcohol on their body.

On the other hand, attitudes toward drinking which say 'Youth drinking is not good' (3.8 point) showed high point regardless of the presence of drinking education. However, results showed a positive response that 'drinking is positive because a few glasses of alcohol are not harmful' (3.95 point), even though most high school students know drinking is not good.

According to the World Health Organization [10], our country's annual liquor consumption per person in 2010 is recorded as 11.80L. Our country's annual alcohol consumption is 11 rank high, which says alcohol consumption of our country already reached high position in the world. This generous drinking culture of the older generation shows the image that such culture is already reflected to minors directly and indirectly. Moreover, the result that the category of 'Adults have to rink for sociability' showed 3.55 point could be proven that adults' drinking culture gives direct and indirect influences to minor drinking. To think alcohol is a necessary sociability tool for personal relationship implies the possibility of drinking even though they think drinking is not a good behavior in youth period but they will become wet by alcohol when they become adult [7].

Such result is not irrelevant to the antinomic attitude of affirmative thinking on drinking allowing teenagers' drinking a small amount of alcohol, while knowing the negative effects of drinking in the youths. In addition, the result supports the fact that most youth think that alcohol is the necessity for harmonious interpersonal relations and is the easiest way to build bridges of interpersonal relations.

$92.4 \%$ of students answered drinking education place was at school and only $6 \%$ at home, which shows the current situations of drinking education in our country. Yang and others [11] asserted in their study that education program should be developed including parents as well as the youths themselves. Especially, he asserted that parent's role is important to make the first drinking starting point after youth period. Considering these results, drinking education cannot be considered to be improved at this current time when 10 years have passed since then, compared with those times when the parents insisted drinking education; and now the countermeasures for this situation can be thought to be required.

Education methods were conducted mainly by lectures and video watching and $53.3 \%$ of educators were external lecturers. The results show that drinking education is one-off and it is being operated just formally. Like the study of Kim [7], it is reasonable to compose the program systematically and concretely regarding the influences of alcohol to body and soul. It is also required that the size of the lecture should be organized with smaller size rather than larger size and should be operated continuously.

Even though various studies about youth drinking education were conducted [11-13], study results with continuous application of drinking educations seem to be insignificant. The best realistic way to improve drinking culture of the youths is to appoint the people in charge of drinking education and to carry out continuous education $[14,15]$. Additionally, further studies to prove the effects of those educations 
are considered to be a necessary assignment, as these studies are actively conducted for the students who have continuously had drinking educations.

This study has a meaning to show that damages caused by drinking could be prevented through education and the improvement of youth drinking cultures is required.

\section{References}

[1] Ministry of Education, http://yhs.cdc.go.kr/, (2013) April 13.

[2] J. Guo, J. D. Hawkins, K. G. Hill and R. D. Abbott, "Childhood and adolescent predictors of alcohol abuse and dependence in young adulthood", Journal of Studies on Alcohol. vol. 62, (2001), pp. 654-762.

[3] A. R. Sohn, Y. S. Lee and M. Y. Yang, "The effect of drinking and self-esteem on depression among high school students: Moderating effect of alcohol consumption”, Journal of Korean Alcohol Science, vol. 12, no.1, (2011), pp. 113-122.

[4] S. D. Ko, "Drinking behaviors linked to sexual intercourse", Journal of Korean Alcohol Science, vol. 13, no.1, (2012), pp. 123-132.

[5] Y. Kaminer and R. E. Tarter, "Adolescent substance abuse", I. M. Galenter and H. D. Kleber, Textbook of substance abuse treatment (3rd ed.), American Psychiatric Publishing, Washington DC, (2004), pp. 505-517.

[6] Ministry of Health and Welfare, http://www.mw.go.kr/front_new/index.jsp, (2013) April 13.

[7] M. J. Kim and M. S. Koh, "A comparative study on female and male high school student's drinking attitude according to factors of drinking related", Journal of Korean Alcohol Science, vol. 9, no. 2, (2008), pp. 73-83.

[8] K. A. Komro, C. L. Perry, M. H. Williams, S. K. Farbakhsh and S. Velben-Mortenson, "How did project Northland reduce alcohol use among young adolesents?", Journal of Health Education Research, vol. 16, no. 1, (2001), pp. 59-7.

[9] Ministry of Health \& Welfare, Korea center for disease control and prevention, http://yhs.cdc.go.kr/, (2013) April 05.

[10] WHO, http://www.searo.who.int/en/Section1174/Section1199/Section2278.htm, (2012) July 26.

[11] S. Yang, H. R. Park, K. Y. Sohng, N. C. Kim, S. J. Jo and J. S. Moon, "High school students alcohol use and related factors", Journal of Korean Academy Psych Mental Health Nurse, vol. 12, no. 3, (2003), pp. 319-328.

[12] W. J. Cho, I. S. Kwon, G. S. Kim and K. M. Seo, "Relationship between problematic drinking behavior and the personalities of high school students", Journal of Korean Community Nsg., vol. 15, no.3, (2004), pp. 471482.

[13] E. H. Choi and M. H. Mo, "Body Image according to body mass index of one area male and female high school and college students", Journal of the Korean Academia-Industrial cooperation society, vol. 14, no.3, (2013), pp. 1313-1319, http://dx.doi.org/10.5762/KAIS.2013.14.3.1313.

[14] D. S. Park, "Effects of life stress and depression of health college students on their suicidal ideation: Control effects of social support", Journal of the Korean Academia-Industrial cooperation society, vol. 14, no.2, (2013), pp. 728-736, http://dx.doi.org/10.5762/KAIS.2013.14.2.728.

[15] M. R. Lee, "The relationship between alcohol use and drinking problems among college students", Journal of the Korean Academia-Industrial cooperation society, vol. 13, no.10, (2012), pp. 4619-4628. http://dx.doi.org/10.5762/KAIS.2012.13.10.4619

\section{Authors}

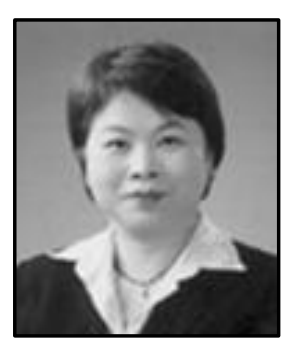

\section{Jin Sook Han}

Aug. 2001 : Chungnam Univ. PhD

March 1995 - current : Konyang Univ. Professor

Research Interests: Health Promotion, Women's Health, Climacterium

- E-Mail : jshan@konyang.ac.kr 


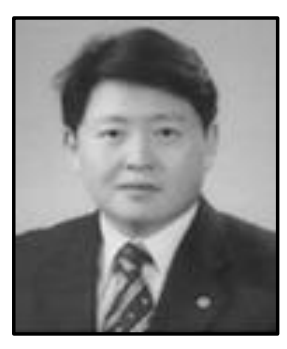

\section{Yomg-Ha Kim}

Feb. 2008 : Sogang Univ. PhD.,

Sep. 2003 - current ; Konyang Univ. Professor

Research Interests: Service Operations Management, Resource Management, BSC,

•E-Mail : kyh@ konyang.ac.kr

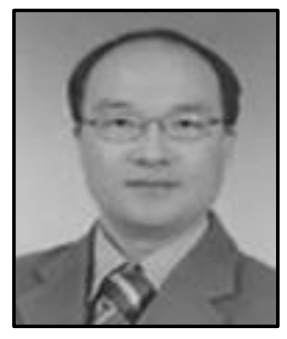

\section{Kwang-Hwan Kim}

Feb. 2003 : Keimyung Univ. Mph.

March 1995 - current : Konyang Univ. Professor

Research Interests: Medical Record, Medical Information, Health Statistcs

•E-Mail : kkh@ konyang.ac.kr 
International Journal of Bio-Science and Bio-Technology Vol.6, No.1 (2014) 